Original Research

\title{
Association of Deslorelin and Sulpiride for Double Ovulation Induction in Mares
}

\author{
Ariel Bertoldi ${ }^{\text {a }}$, Lorenzo Garrido Segabinazzi a , Camila de Paula Freitas Dell'Aqua ${ }^{a}$, \\ Jose Antonio Dell'Aqua Junior ${ }^{\mathrm{a}}$, Marco Antonio Alvarenga ${ }^{\mathrm{b}, *}$ \\ a Department of Animal Reproduction and Veterinary Radiology, College of Veterinary Medicine and Animal Science, Univ Estadual Paulista (UNESP), \\ Botucatu, Sao Paulo, Brazil \\ ${ }^{\mathrm{b}}$ Department of Animal Reproduction and Veterinary Radiology, College of Veterinary Medicine and Animal Science-(UNESP)/Univ Estadual Paulista, \\ Botucatu, Sao Paulo, Brazil
}

\section{A R T I C L E I N F O}

\section{Article history:}

Received 19 June 2018

Received in revised form

18 July 2018

Accepted 18 July 2018

Available online 21 August 2018

\section{Keywords:}

Equine

GnRH

superovulation

antidopaminergic

dopamine

\begin{abstract}
A B S T R A C T
The aim of this study was to verify the effect of deslorelin and sulpiride association on double ovulation induction in mares. Ten mares were used for this study. Eight days after ovulation, luteolysis was induced and mares were submitted a daily ultrasonographic evaluation until observation of at least two follicles measuring between 20 and $25 \mathrm{~mm}$. Animals were split in two experimental groups in a crossover study. In deslorelin (DES) group, the animals received $150 \mu \mathrm{g}$ deslorelin, intramuscularly, every 12 hours, until the second largest follicle reached at least $33 \mathrm{~mm}$ in diameter, at which time ovulation induction was performed with 1.500 IU of human chorionic gonadotrophin, IV. In the DES + sulpiride (SULP) group, the treatment was performed in the same manner as in the DES group, associated with the administration of $1 \mathrm{~g}$ of sulpiride, orally, once daily until the time of ovulations induction. In both groups, ultrasound examinations were performed daily to evaluate follicular development and the detection of ovulations. Double ovulations were observed in 70\% (7/10) of the animals of the DES group and 50\% (5/10) of the animals in the DES + SULP group. The percentage of ovulations corresponding to the number of follicles developed was $81.8 \%$ (18/22) for the DES group and 79\% (15/19) for the DES + SULP group, and no difference was observed between the groups $(P>.05)$. We conclude that association of sulpiride with deslorelin acetate did not contribute to the increase in double ovulations in mares.
\end{abstract}

(C) 2018 Elsevier Inc. All rights reserved.

\section{Introduction}

To improve reproductive efficiency in mares, an alternative is to increase the number of ovulations per cycle, which would lead to an increase in embryo recovery rates, consequently reducing the costs involved in embryo transfer programs [1]. Treatments to induce multiple ovulations in mares have been described by several

Animal welfare/ethical statement: The study "ASSOCIATION OF DESLORELIN AND SULPIRIDE FOR DOUBLE OVULATIONS INDUCTION IN MARES" was approved by the Ethics and Animal use Committee, with protocol number 0177/2017, from the São Paulo State University (UNESP), Botucatu campus, SP, Brazil.

Conflict of interest statement: The authors declare no conflicts of interest.

* Corresponding author at: Marco Antonio Alvarenga, Department of Animal Reproduction and Veterinary Radiology, College of Veterinary Medicine and Animal Science-(UNESP)/Univ Estadual Paulista, Distrito de Rubião Junior, s/n, Botucatu, Sao Paulo 18618-970, Brazil.

E-mail address: malvarenga@fmvz.unesp.br (M.A. Alvarenga). authors, however, followed by reduced embryo recovery rates because they decrease with the great number of ovulations [2-6], due to the fact related to the formation of a large clot in the ovulation fossa, which impairs the transport of oocytes to the oviduct after ovulation [6]. Thus, embryo recovery rates may be high if the number of ovulation per ovary is limited to two or three [6].

Among the hormones used for this purpose, equine pituitary extract and purified equine follicle stimulating hormone are the most studied drugs. However, the difficulty of acquisition, added with the high cost and inconstant results of these hormonal preparations, limit the diffusion of superovulation in the equine species [7]. The use of low-cost, high-availability, synthetic hormone such as deslorelin acetate has been studied to induce double ovulation in mares, with multiple ovulation rates being observed in about $70 \%$ of mares submitted to treatment [7-11].

Sulpiride promotes the production of prolactin that acts directly on follicle stimulating hormone (FSH) and luteinizing hormone 
(LH) receptors of the follicles [12]. Studies reported the efficiency of sulpiride in hastening cyclicity in mares in anestrus [13] and in transition phase [14]. Considering that inhibin, a hormone FSH suppressor, is secreted by the dominant follicle causing atresia of the other follicles, but this one still growing by the relative FSH independence, due to the higher amount of FSH and $\mathrm{LH}$ receptors in granulosa cells [15], sulpiride appears as a possible strategy to improve receptor expression in the second largest follicle, improving follicles' capacity to grow until preovulatory size, raising the percentage of mares that respond to the treatment of double ovulation induction. In this context, the aim of the present study was to verify the effect of sulpiride and deslorelin association for double ovulation induction in mares.

\section{Material and Methods}

This study was approved by the Animal Care and Use Committee of São Paulo State University with protocol number 0177/2017.

\subsection{Animals}

Ten crossbreed mares, with ages ranging from 3 to 20 years and weighing between 350 and $450 \mathrm{~kg}$, from the Equine Breeding Center-CER, located in Boituva City/SP were used. The animals were maintained in paddocks formed by coast-cross grass (Cynodon dactylon), with free access to water and mineral salt, receiving $4 \mathrm{~kg}$ of commercial ration for equines, twice a day.

\subsection{Ultrasonographic Control}

Ultrasound evaluation was performed daily using a $5 \mathrm{MHz}$ linear transducer (Mindray DP2200Vet, Shenzhen, China) to identify follicular development and ovulation. The follicular diameter was obtained considering the average of the two linear measurements of the antrum taken at right angles.

\subsection{Experimental Groups}

The experiment was performed between January and March of 2017. Four cycles of each animal were used. The first cycle with the objective of evaluating follicular development and ovulation served as pretreatment control. Animals that had double spontaneous ovulations and ovulation failures were not used in this study. The last cycle was followed to verify possible changes in the follicular dynamics as a function of the treatments performed, without pharmacological manipulation. Between the pretreatment and posttreatment control cycles, two cycles of each animal were used for the experiment. Eight days after ovulation, ultrasonographic examination was performed to confirm the presence of corpus luteum and to evaluate the follicular population in the ovaries. At this time, $5 \mathrm{mg}$ of dinoprost tromethamine (Lutalyse, Pfizer, New York, USA) were injected intramuscularly (IM) to perform luteolysis, and ultrasonographic examinations were performed daily. When at least two follicles between 20 and $25 \mathrm{~mm}$ were observed, the animals were randomly assigned to one of the two treatment groups (DES [deslorelin] group or DES + SULP [sulpiride] group). In the subsequent cycle, the mares were changed in groups, following the cross-over model. Ovulation inductions were performed when the second largest follicle reached at least $33 \mathrm{~mm}$ or the largest follicle $\geq 38 \mathrm{~mm}$, and grade 2 uterine edema [16] with 1500 IU of human chorionic gonadotrophin (hCG-Vetecor Laboratório Calier, São Paulo, Brazil), intravenously. In the DES group, 150 micrograms $(\mu \mathrm{g})$ of deslorelin acetate (Sincrorrelin, Ouro Fino, Brazil) was administered IM, every 12 hours, until ovulation induction. Ultrasound examinations continued until ovulation was observed. In the
DES + SULP group, deslorelin acetate applications were performed as described previously, concomitantly with the administration of 1 $\mathrm{g}$ of sulpiride (Drogavet-Veterinary Handling Pharmacy-Curitiba, Paraná, Brazil) orally, every 24 hours, until the time of ovulation induction. In animals that follicular growth was not observed after 3 days of treatment, it was interrupted to avoid downregulation, as observed in a recent study [7], and the animal was evaluated until a corpus luteum $(\mathrm{CL})$ is diagnosed and the next cycle was used.

\subsection{Statistical Analysis}

Statistical analyses were performed using GraphPad Prism version 6.0. First, a descriptive analysis of the parameters (mean and standard error) according to the experimental conditions and evaluation of normality by the Kolmogorov-Smirnov (K-S) test were performed. As all data were considered nonparametric, a Mann-Whitney test was used. The percentages were analyzed by the Fisher's test. Statistical significance was considered when $P<$ .05 .

\section{Results}

The interval between application of prostaglandin F2 $\alpha$ (PGF2 $\alpha$ ) and beginning of treatment was $3.6( \pm 0.4)$ and $4( \pm 0.2)$ days for the DES and DES + SULP groups, respectively. The mean number of follicles between 20 and $25 \mathrm{~mm}$ at the beginning of treatment was similar between groups. The diameter of the largest follicle and second largest follicle at the beginning of treatment did not differ between groups $(P>.05)$. The mean duration of treatment for induction of ovulation was $3.3( \pm 0.2)$ and $4( \pm 0.3)$ days for the DES and DES + SULP groups, respectively (Table 1$)$. The number of mares that developed at least two follicles $\geq 33 \mathrm{~mm}$ did not differ between groups (DES-90\%; DES + SULP-70\%), as well as the mean number of follicles $\geq 33 \mathrm{~mm}$ per mare at the time of ovulation induction (DES-2.2; DES + SULP-1.9) $(P>.05)$. The diameter of the largest follicle (DES-36.7; DES + SULP-35.9) at the time of induction did not differ between groups, but a difference in the diameter of the second largest follicle (DES-35.1; DES + SULP-33.1) at the same time $(P<.05)$ was observed (Table 1$)$. The mean number of ovulations did not differ between groups, considering 1.8 and 1.5 ovulations for the DES and DES + SULP groups, respectively. Most of the mares ovulated in synchrony up to 24 hours, with $71.4 \%$ (5/7) for the DES group and $80 \%$ (4/5) for the DES + SULP group. Asynchronous ovulations were observed in two mares (28.5\%) in the DES group and one mare (20\%) in the DES + SULP group. The number of mares that ovulated two follicles did not differ between groups (DES-70\%; DES + SULP-50\%). When we evaluated the number of ovulations corresponding with number of follicles developed above $33 \mathrm{~mm}$ in diameter, 18/22 (81.8\%) in DES group and 15/19 (79\%) in DES + SULP group were observed with no difference between them $(P>.05)$. The interval between the application of PGF $2 \alpha$ and the next ovulation did not differ between groups (Table 1).

In the first cycle, before start the experiment, and the last cycle after finished the experiment, all mares presented normal follicular development $(9 \pm 1.6$ days between PGF $2 \alpha$ application and ovulations) and ovulation (one ovulation per cycle).

\section{Discussion}

Studies on the induction of double ovulation in mares using deslorelin acetate have recently been described with satisfactory results $[7,9-11,17]$. Because it is a gonadotropin-releasing hormone $(\mathrm{GnRH})$ analog, deslorelin acetate stimulates the secretion of gonadotrophins by the pituitary gland fostering follicular growth [18]. 
Table 1

Mean data and standard error of the variables between the group treated with deslorelin and the group treated with deslorelin + sulpiride to obtain double ovulations.

\begin{tabular}{|c|c|c|}
\hline Variables & DES & DES + SULP \\
\hline Number of cycles used & 10 & 10 \\
\hline Time after application of PGF2 $\alpha$ and initiation of treatment (d) & $3.6 \pm 0.4$ & $3.2 \pm 0.2$ \\
\hline Number of follicles $\geq 20 \mathrm{~mm}$ at initiation of treatment & 28 & 29 \\
\hline Number of follicles $\geq 20 \mathrm{~mm}$ at initiation of treatment per mare & $2.8 \pm 0.2$ & $2.9 \pm 0.3$ \\
\hline Diameter of the largest follicle at initiation of treatment $(\mathrm{mm})$ & $24.1 \pm 0.3$ & $23.8 \pm 0.3$ \\
\hline Diameter of the second largest follicle at initiation of treatment ( $\mathrm{mm}$ ) & $22.4 \pm 0.4$ & $22.5 \pm 0.2$ \\
\hline Days of treatment until ovulation induction & $3.3 \pm 0.2$ & $4.0 \pm 0.3$ \\
\hline Diameter of the largest follicle at ovulation induction (mm) & $36.7 \pm 0.6$ & $35.9 \pm 0.2$ \\
\hline Diameter of the second largest follicle at ovulation induction (mm) & $35.1 \pm 0.6^{*}$ & $33.1 \pm 0.1^{*}$ \\
\hline Number (\%) of mares with at least two follicles $\geq 33 \mathrm{~mm}$ at ovulation induction & $90 \%(9 / 10)$ & $70 \%(7 / 10)$ \\
\hline Number (\%) of mares with no follicle development $\geq 33 \mathrm{~mm} 3 \mathrm{~d}$ after starts treatment & $0 \%(0 / 0)$ & $10 \%(1 / 10)$ \\
\hline Number of follicles $\geq 33 \mathrm{~mm}$ at ovulation induction & 22 & 19 \\
\hline Average number of follicles $\geq 33 \mathrm{~mm}$ per mare at ovulation induction & $2.2 \pm 0.2$ & $1.9 \pm 0.3$ \\
\hline Number (\%) of mares with at least two ovulations & $70 \%(7 / 10)$ & $50 \%(5 / 10)$ \\
\hline Number (\%) of mares with one ovulation & $30 \%(3 / 10)$ & $40 \%(4 / 10)$ \\
\hline Number (\%) of mares with synchronous ovulations up to $24 \mathrm{~h}$ & $71.4 \%(5 / 7)$ & $80 \%(4 / 5)$ \\
\hline Number (\%) of mares with asynchronous ovulations $>24 \mathrm{~h}$ & $28.5 \%(2 / 7)$ & $20 \%(1 / 5)$ \\
\hline Number of ovulations & 18 & 15 \\
\hline Average number of ovulations per cycle & $1.8 \pm 0.2$ & $1.5 \pm 0.2$ \\
\hline Number $(\%)$ of follicles $\geq 33 \mathrm{~mm}$ did not ovulate & $18.1 \%(4 / 22)$ & $21 \%(4 / 19)$ \\
\hline Number (\%) of ovulations versus follicles submitted to ovulation induction & $81.8 \%(18 / 22)$ & $79 \%(15 / 19)$ \\
\hline Interval between PGF $2 \alpha$ and ovulation (d) & $9.6 \pm 0.6$ & $8.8 \pm 0.5$ \\
\hline
\end{tabular}

Abbreviations: DES, deslorelin; PGF2 $\alpha$, prostaglandin F2 $\alpha$; SULP, sulpiride.

${ }^{*} P<.05$.

In addition to being a synthetic hormone and not presenting variation between the departures, deslorelin acetate has low cost and high commercial availability [7].

The treatment period with deslorelin in the present experiment was approximately 4 days, sufficient time for the follicles to reach adequate diameter for the ovulation induction. Irvine [19] described that prolonged treatment with GnRH in several species may induce pituitary desensitization, causing a decrease in gonadotrophin secretion and consequently a decrease in ovarian activity, a phenomenon known as downregulation. This phenomenon could also be observed in a study by Nagao et al [7]. In the present study, no downregulation was observed in any of the treated animals. One of the mares of the DES + SULP group did not show follicular growth after 3 days of treatment, and it was immediately stopped.

A dopamine antagonist drug, sulpiride, has been linked to increased serum prolactin levels, which in turn regulate the receptor population for FSH and LH in the ovaries [12]. Considering the lower condition of the second largest follicle to reach dominance, due to its lower expression of FSH and $\mathrm{LH}$ receptors, as observed by Bergfelt and Adams [15], it was decided to associate sulpiride with deslorelin treatment in an attempt to elevate the receptor population for FSH and $\mathrm{LH}$ in the codominant follicle, thus enabling its growth until ovulation. A recent study in the attempt to stimulate multiple ovulations in cyclic mares using sulpiride close to the follicular dominance demonstrated the efficacy of the treatment stimulating ovarian activity but did not contribute to a significant increase in rates of multiple ovulations [20]. When administered orally in horses, the absorption of sulpiride is considered relatively low, around 20\% [21]. Taking this fact into account, the dose chosen was higher (about $2.5 \mathrm{mg} / \mathrm{Kg}$ ) than used in other studies where it was possible to verify serum prolactin elevation following administration of sulpiride IM in mares in the transition phase $[13,22]$. In addition, it was reported the efficacy of sulpiride in elevating serum prolactin levels after administration of $2 \mathrm{mg} / \mathrm{kg}$, orally, in postpartum mares [23] and at $1.5 \mathrm{mg} / \mathrm{kg} \mathrm{IM}$ in mares in the periovulatory period [24].

Considering rates of follicular development and ovulation, the results observed in the present study were similar to those obtained in recent studies where deslorelin was used to induce double ovulations in mares [7-11]. When evaluating the rate of double ovulation, 70\% (7/10) of the mares obtained at least two ovulations when treated with deslorelin because one of them ovulated three follicles. This result was similar to those reported in other studies where deslorelin was used, ranging from $70 \%(7 / 10)$ [9], 79\% (39/43) [8], 82\% (46/56) [7], and 86.6\% [10]. Superior results were described in another experiment, where all mares ovulated two follicles (10/10) [17]. Already in a study conducted by Lima et al. [25], only $25 \%(3 / 12)$ of the mares responded with double ovulation.

The association of sulpiride and deslorelin for double ovulation induction was proposed with the intention to increase the percentage of mares that respond to the treatment with deslorelin, a fact that could not be observed, because in the group where the sulpiride was added to the treatment, only $50 \%(5 / 10)$ of the animals ovulated at least two follicles.

The mean diameter of the second largest follicle in the mares of the DES + SULP group was lower compared to mares receiving deslorelin only $(P<.05)$. In a study conducted by Campos et al. [17] in which follicles from $33 \mathrm{~mm}$ were submitted to ovulation induction with 1500 IU of hCG, 100\% (10/10) of the mares presented double ovulation. Similarly, Nagao et al [7] and Carmo et al [8] obtained satisfactory rates of double ovulation when induction was performed on follicles $\geq 33 \mathrm{~mm}$ with $2.500 \mathrm{IU}$ of hCG. Although these authors report efficacy in ovulation induction of follicles from $33 \mathrm{~mm}$ in diameter, others recommend that the ovulation induction hCG be performed from the observation of follicles $\geq 35 \mathrm{~mm}$ $[11,26,27]$. Thus, waiting one more day to ovulation induction in the DES + SULP mares, at which point the second largest follicle would probably reach a diameter of $\geq 35 \mathrm{~mm}$, could have increased the number of mares with double ovulation in this group.

Most of the ovulation occurred synchronously in both groups, which becomes extremely important when artificial insemination is performed using refrigerated or frozen semen, thus increasing the embryo recovery rates from a single insemination per cycle.

The mean interval between the application of PGF2 $\alpha$ and the next ovulation was similar between the treated groups and in the pretreatment and posttreatment control cycles, demonstrating that 
ovarian stimulation did not interfere in the interval between luteolysis and ovulation in the posttreatment cycle.

No improvement in ovarian response was observed in the animals treated with the association of deslorelin and sulpiride when compared to the group treated with deslorelin alone. We conclude that the association of sulpiride and deslorelin acetate did not contribute to the increase in double ovulations rates in mares.

\section{References}

[1] Alvarenga MA, Carmo MT, Landim-Alvarenga FC. Superovulations in mares: limitations and perspectives. Pferdeheilkunde 2008:24:88-91.

[2] Alvarenga MA, Mccue PM, Bruemmer J, Neves Neto JR, Squires EL. Ovarian superstimulatory response and embryo production in mares treated with equine pituitary extract twice daily. Theriogenology 2001;56:879-87.

[3] Squires EL, Carnevale EM, Mccue PM, Bruemmer JE. Embryo technologies in the horse. Theriogenology 2003;59:151-70.

[4] Farinasso A, Branquinho JA, Rumpf R, Alvarenga MA. Use of low doses of equine pituitary extract to induce multiple ovulations in mares. Acta Scientiae Veterinarie 2005;33:135-8.

[5] Alonso MA, Fleury PDC, Alvarenga MA. Effect of frequency of low dose treatment of equine pituitary extract on induction of multiple ovulations in mares. Acta ScientiaeVeterinarie 2006;34(Suppl 2):532.

[6] Carmo MT. Study of follicular fluid, transport, recovery and maturation of oocytes in superovulated mares with equine pituitary extract. Botucatu/SP Thesis (doctorate)-Faculty of Veterinary Medicine and Animal Science, State University of São Paulo Júlio de Mesquita Filho; 2007.

[7] Nagao JF, Neves JR, Papa FO, Alvarenga MA, Dell'aqua CPF, Dell'aqua JA. Induction of double ovulation in mares using deslorelin acetate. Anim Reprod Sci 2012:136:69-73.

[8] Carmo MT, Sales JNS, Bastos MR, Maio JRG. Effect of deslorelin acetate on follicular development and obtaining multiple embryos in cyclic mares. 2013 Available at: http://www.ourofinosaudeanimal.com. [Accessed 10 May 2017].

[9] Steigleder LF, Rodrigues R, Oliveira OGA, Kaipper RR, Rei JM, Rodrigues TS, Gonçalves LM, Segabinazzi L, Neto CR, Alvarenga MA. Induction of multiple ovulations in mares with low doses of deslorelin without follicular follow up prior to the beginning of treatment. Anais XV Annual Conference Abraveq. São Paulo: Campos do Jordão; 2014.

[10] Azevedo MV, Souza NM, Ferreira-Silva JC, Batista IO, Moura MT, Oliveira MAL Alvarenga MA, Lima PF. Induction of multiple ovulations in mares using low doses of GnRH agonist Deslorelin Acetate at 48 hours after luteolysis. Pferdeheilkunde 2015;31:160-4.

[11] Segabinazzi LG, Steigleder LF, Kaipper R, Rodrigues TS, Aragon O, Dell'Aqua Jr JA, Alvarenga MA. Induction of multiple ovulations in mares with low doses of deslorelin acetate without prior follicular follow-up. Enciclopédia Biosfera 2015;11:1488-94.
[12] Tibary A. Dopamine antagonists. In: Mckinnon AO, VOSS JL, editors. Equine reproduction 2. Philadelphia: Lea \& Febiger; 2011. p. 1788-93.

[13] Dales PF, Fatone S, Hansen BS, Concannon PW. Dopamine antagonist-induced reproductive function in anoestrous mares: gonadotrophin secretion and effects of environmental cues. J Reprod Fertile 2000;56:173-83.

[14] Panzani D, Zicchino L, Taras A, Marmorini P, Crisci A, Rota A, Camillo F. Clinical use of dopamine antagonist sulpiride to advance first ovulation in transitional mares. Theriogenology 2011;75:138-43.

[15] Bergfelt DR, Adams GP. Ovulation and corpus luteum development. In: Samper JC, Pycock JF, Mckinnon AO, editors. Current therapy in equine reproduction; 2007. p. $1-13$.

[16] Samper JC. Induction of estrous and ovulation: why some mares respond and others do not. Theriogenology 2008;70:445-7.

[17] Campos DG, Sá PV, Souza PNC, Strauuch MA, Carmal CFM, Martins AV, Dell 'Aqua Jr JA, Pinna AE. Induction of double ovulation in mares using deslorelin acetate. Anais XV Annual Conference Abraveq. São Paulo: Campos do Jordão; 2014.

[18] Ginther OJ, Bergfelt DR. Effect of GnRH treatment during the anovulatory season on multiple ovulation rates and on follicular development during the current pregnancy in mares. J Reprod Fertil 1990;88:119-26.

[19] Irvine CHG. Gonadotropin-releasing hormone. J Equine Vet Sci 1983;3: 168-70.

[20] Cruz FASM. Effect of administration of sulpiride on follicular development in mares. São Paulo, Brazil: Faculty of Veterinary Medicine and Animal Science, State University of São Paulo Júlio de Mesquita Filho, Dissertation; 2014.

[21] Giorgi M, Mehmet O, Camilo F, Panzani D. Pharmacokinetics of sulpiride after intravenous, intramuscular, and oral single-dose administration in nurse mares. J Equine Vet Sci 2013;33:533-8.

[22] Mari G, Morganti M, Merlo B, Castagnetti C, Parmeggiani F, Govoni N, Galeati G, Tamanini C. Administration of sulpiride or domperidone for advancing the first ovulation in deep anestrous mares. Theriogenology 2009;71:959-65.

[23] Migdal A, Migdal L, Zagrajczuk A, Kochan J, Nowak A, Okloski A. Influence of sulpiride treatment on the level of prolactin and immunoglobulins in the peripheral blood of mares during the postpartum period. Acta Vet Hung 2017;65:417-28.

[24] Martínez-Bovi R, Zagrajczuk A, Domingo-Ortiz R, Cuervo-Arango J. The effect of sulpiride treatment during the periovulatory period on prolactin concentration and ovulation in the mare. J Equine Vet Sci 2014;34: 1170-4.

[25] Lima LGF, Kozicki LE, Dell'Aqua Jr JA, Camargo CE, Polo G, Santos IP, Macan RC, Lara P, Alberini V. The use of deslorelin acetate for the stimulation and induction of double ovulations in mares. Anais XVI Annual Conference Abraveq. São Paulo: Águas de Lindóia; 2015.

[26] Gastal EL, Silva LA, Gastal MO, Evans MI. Effect of different doses of hCG on diameter of the preovulatory follicle and Interval to ovulation in mares. Anim Reprod Sci 2006;94:186-90.

[27] Newcombe JR. Human chorionic gonadotropin. In: McKinnon AO, Squires EL Vaala WE, Varner DV, editors. Equine reproduction. 2 Ed., vol 179. Ames: Wiley-Blackwell; 2011. p. 1858-69. 